\title{
A Historical Overview and Initiating Historiography of Islam in the Philippines
}

\author{
Ajid Thohir ${ }^{1}$ \\ 1 Faculty of Adab and Humanities \\ Universitas Islam Negeri Sunan Gunung Djati Bandung, Indonesia. \\ Email: ajid_thohir@yahoo.com
}

\begin{abstract}
:
Understanding the history of Islam in the Southeast Asia will be more accurate through the geopolitical and historical background perspective in particular. This assumption is based on Western Colonial influence in the past such as Spanish, Portuguese, Dutch, British, French, and United States that makes up the typology of Islamic culture in South East Asian region, which is strengthens the plurality of Islamic character. It also seems increasingly clear, especially for the Muslim communities in Philippine, who represented the community formed of Moro Islamic movement. Islamic culture in the Philippine is produced by the Spanish and the United States colonial policy which determines the fate and the treats of Muslims as a conquered state. This historical background results the emergence of a heroic character in Philippines Muslims that is different from the other Muslims community in South East Asia who are relatively considered quiet and peaceful. This paper will briefly explain the historiography of Islam in South East Asia region through involving cases of Muslims in the Philippine who will not found the plurality of character in the other country.
\end{abstract}

Keywords: Historiography, Islamic Culture, Islamic Character Muslims Community, Plurality.

\section{A. INTRODUCTION}

The entry, growth, and development history of Islam in Southeast Asia, particularly in the aspects of culture and civilization, is still not fully exposed thoroughly (Cf., Weiss, 2010, Liow, 2015, Thaib \& Pa, 2013, Ahmad, 2007, Bahar, 2012, Shuhaimi, 2014, Shamsul A.B., 2005, Aljunied,2004, Jalil, 2014, Daneshgar, 2014). One of the reasons is that some studies with various aspects of the history of Islam in Southeast Asia, especially in the base region of Malay culture, which were conducted by some foreign and native historians still cannot be formulated concretely - as a historical paradigm that can be used collectively - with each conclusion is still difficult to be reconciled with one another (Azra, 1989).

There are at least three major theories regarding the origin of the Islam arrival to Southeast Asia. The first theory states that Islam came directly from Arab (Hadramaut). The second theory states that Islam came from India, the Gujarat and Malabar, and also from Bengal (now Bangladesh). The third theory states that Islam came from Persia which is evidenced by the many traditions and culture of Persian and Shiite which enter our archipelago reflected in the models of religious ceremonies like the ark in Minangkabau, learning methods such as reading the Quran using the Baghdadiyah method (the terms of jabar, pees, jeer, and so on), the terms of bazaar 
(market), Mulud Fatimah (the birth of Fatimah), the Ark on 10 Muharram, and so on (Hafid, 2012 and Jalil, 2014).

The fourth theory states that Islam came from Kurdistan based on the evidence that many various Malay names are derived from the Kurdistan language. Although there is no agreement, the author considers it seems their needs to be openness to write and bring new interpretations so that research on historical sources can be revealed and reviewed comprehensively (Benjamin, 1982).

There is actually information on historiography in the forms of saga, genealogy, chronicle, stories, poems, and many more that reveal the development of Islam in Southeast Asia (Lombard, 1996) among the Indigenous community. But most of them contain "myth" rather than "history" in the Western sense. Therefore, our assessment lies not only on the historical value, but also understanding the symbols used widely as the historical source. It is because saga, genealogy, chronicle, stories, poems, and many more other stories can certainly value on its authenticity. This authenticity is the capital base to ensure that the source is feasible to be used as the historical source. For example, if the source prevailing historical writings in the Christian and Europe tradition simply attached to the Islamic tradition, in turn, it may lead people on misconceptions and distortions in viewing Islam. That is why for those who want to seek for objectivity; foreign sources are not more reliable than indigenous sources (Benjamin, 1982).

Hence the effort on discussions on this Malay Islamic study needs to identify the various cultural behavior of each regional or national territory. Furthermore, it is likely to use a holistic view on the primary issue involved so that the results can be understood as a historical reconstruction as a whole. Thus, the construct is no longer just narrative-descriptive, but also includes a generalization on the pattern of explorative social and cultural, in addition to giving meaning to the facts. Finally, by briefly exposing the historical facts concerning the various socio-cultural phenomena, we place the historical truth at the level of generalization based on the rules of social history approach scientific principles (Burke's, 2003).

Describing the characteristics of the development and the pattern of social life, religion, and culture of the Malay Muslims in Southeast Asia, regarding the cultural dynamics of each community area, must show complex and free patterns. The ethno-linguistic sides of each nation-state in this region show the position homogeneous. On the other hand, political patterns and dynamics of regional territories logically require a very different development.

Furthermore, it is viewed from the point where the geographical area of Malay is very different from other culture areas since it is an island country. In addition, the colonial that developed Malay's nationalism was and also quite diver as England, Netherland, Portuguese, and Spain, and Japanese. Each invader nation has given strong enough colors for the mental development of nationality following the establishment of the future State of the Union system.

Their heterogeneity is seen in many respects such as when the Asia-Pacific region, particularly the Malay nations in Southeast Asia face problems on economic globalization. Each country has taken its own policies on its on different attitude and pattern according to the political developments and their demographic position. It also includes issues and challenges of the Malay and Southeast Asia Muslim in facing Western secularism; even the form of the problem is the same in brief. 
However, the forms of responses and the opportunities to answer the problems are in different patterns and ways. Malaysia and Brunei Darussalam are more monolithic and rigid on one side of the schools of figh development or arrangement of such religious understanding (e.g. understand shafi'iya only). While religious attitudes in Indonesia appears to be more liberal and free in adopting religious ideas, especially figh where there are Muhammadiyah, Persis, and Nahdlatul Ulama, all of which have taken a stance on the four schools of figh openly (Thohir, 2011)

\section{B. METHODS}

The study of historiography is the core of the many problems faced by the researchers of history (Adeoti \& Adeyeri, 2012). The form of historiography developed and emerged is reflected from any kinds and forms of historical phenomena, various sources, themes and methodology used and conducted; how "some object" was reconstructed, explained, and narrated in different rhetoric.

Problems of historical sources have become a classic discussion for historians, as a source of history is the only benchmark for the development of historiography itself (Cook, 2011). Why? Because history is built not only upon the power of imagination, but also based on the reality that indeed happens, although each historical fact is also debatable and has a value of controversy (Thomas, 2014). But the point is that whatever the result, Islamic historiography must continue to evolve from the inside along with the actual development of the Islamic world (Negoiță, 2014) recognizing the modern world of globalization and do not let outsiders "more powerful" in describing the reality of the Islamic world.

\section{RESULT AND DISCUSSIONS}

\section{Islam in the Philippines; From the Sultanate of Mindanao to Islamic Moro?}

In the case of the Philippines, the relation history between Muslims in the South or the Moro and the colonial ruler of Spain is the history of the eternal confrontation. After the military occupation from 1899 to 1903, the Moro province was founded from 1903 until 1913 as a political and military unit. The regions of Mindanao and Sulu were founded from 1914 to 1920, soon after that, the Muslim affairs were handled by the Philippine government (Majul, 1989).

Regardless the efforts to integrate the region administratively and to enclose the secular education, organizations of Muslim society in Philippines hold tight on the tradition. Religion is a major problem. Islamic religious education continues to play an important role in community socialization (Majul, 1989). The effects after colonialism in the Philippines were Christianization and Nationalization, which caused anxiety among Muslims on the future (Majul, 1989). It was suspected by the Islamic community that the Islamic impression in the island of Minadanau would vanish because of the sovereignty of the Republic Philippines was restored on July 4th, 1946, in addition to the law year 1935, which then adopted the American model of the democratic government system (Kahin, 2003). 
The Philippines is an archipelago of 7,107 islands. Its population is 47 million people using 87 different dialects, which reflect many tribes and ethnic communities (Majul, 1989). Islam has had a long history in the Philippines. Since the pre-colonial era, the Muslim community in the southern part recorded as a society that was able to defend themselves from the penetration of Spain for three hundred years. Only since the beginning of the twentieth century in the southern region of the Muslims began to put together administratively and systematically into the wider political community although there were a lot of obstacles (Hooker, 1983).

The Muslims in the Philippines called themselves as Moro. However, this name is actually more political, because in reality Moro consists of many ethnolinguistic groups, for example the Maranao, Maguindanao, Tausug, Samal, Yakan, Ira Nun, Jamanapun, Badjao, Kalibugan, Kalagan, and Sangil (www.lonelyplanet.com). The number of Muslim communities is around 4.5 million or $9 \%$ of the entire population of the Philippines (Mastura, 1984). In the Sulu, there are still the majority of the population, namely Tawi-Tawi, Zamboanga de Sur, Maguindanao, Zamboanga de Norte, Northj Cotabaco, Sultan Kudarat, Lanao del Norte, Lanao del Sur, South Cotabato, Palawan, and Basilan.

The majority of the Moro people are fishermen and farmers. Moro people believe that they are different from other Philippines. The real difference is not in the ethnic factor because there are nearly 100 ethnic groups in the Philippines, but it is rather on the political history factors, region, religion, and socio-economic conditions.

Considering their work activities, The Islamic Moro people also work in the government sectors as teachers, administrators, army, employees of the judicial office, and even elected as the governor. Muslims who received secular education tend to be able to blend with the other Philippines. On the other hand, those who do not want to receive the secular education and only get the traditional religious education, especially the local elite were educated in the Middle East, usually do not expect integration with the Philippines. There is a fairly wide gap among Muslim communities, especially between the traditional elites and the common masses. Identification and ethnic consciousness that occur due to the division of the Muslim communities geographically seems very strong. Although there are variations and differences, there is a feeling of religious brotherhood, especially when they are faced with the same problem (Ahmad Ibrahim, 1989).

For example, when there was a policy to put Christians in Mindanao, it consequently generated Muslim Independent Movement (MIM) in the 1960s. Then, the emergence of subsequent movements such as the Moro National Liberation Front (MNLF) and the Moro nation Army (BMA) who fought for the Muslims in the Philippines should be seen in the context of the growing frustration among Muslim communities in the South because they are exiled economically and in politics (Majul, 1989).

An emergency condition in 1972 imposed by President Marcos led to further deterioration of law enforcement. The new society that Marcos wanted to build was an attempt to repair the evils that hit the Philippines as a country. Muslims of course were affected; but at the level of the government, they were given concessions. Muslims rebellion was seen as not worth and unnecessary. 
The Tripoli treaty which attempted to stop the conflict between the MNLF and the government was held. The government had taken the positive steps to show concern and good trust on this problem. One of them was the establishment of Philippine Pilgrimage Authority, an agency of development and well-being, and the implementation of family law for Muslims (Majul, 1989).

The recent political changes in Filipina have caused anxiety for the Muslim community. The experiment of democracy in Central Philippines had passed through the crucial phase. A positive attitude towards Muslims Philippines will help to ease the burden of President Fidel Ramos (Bresnan, 1988). While Negotiations continued, the ceasefire was not one hundred percent effective yet. Fidel Ramos, Nur Misuari (Tausug), and Hashim (Maguindanao) continued national political reconciliation in the broad sense, with all groups and Indonesia was willing to mediate, and it was held in Jakarta.

The reviews show that the phases of the Moro sketched the relationship between community studies, history, and religion. In the methodology of Islamic studies, it cannot be assessed separately because the complexity is included in the social science. In the $70 \mathrm{~s}$, Michael 0. Masturs and Adib Majul had filled a critical void in the literature of social science on Muslims in the Philippines. In public policy, both Michael O. Masturs and Adib Majul managed to draft a code of laws for Muslims in Philippines which are now approved as PD No. 1083. It has generated a new research direction of Sharia law and the administration and justice development in Southeast Asia.

Change of political regime has opened the way for economic reforms. Michael 0 . Masturs and Adib Majul proposed HB 4996 that the draft was made by them to the Charter of the Islamic Investment Bank of the Philippines. With this bank, it was expected that Muslims could enter the contemporary financial engineering. It means that their intellectual and creativity contributions have concretized the socio-economic aspirations of the Muslims in Philippines. The new approach has also donated a new terminology in the trading and banking law issues. There is a correspondence between the ideas the law interpretation of ijtihad and the legislative goals through siyāsa.

The application of this law has opened the way for institutional procedure to create an international consensus carried out by the agency in order to establish the unity of the Islamic bank. With this, consensus could already be made. The development of laws governing Islamic banks needs a "scouting law". The law is as a legal transaction in Malaysia, Pakistan, Bangladesh, Egypt, Iran, Sudan, Nigeria and the Gulf countries as well as on a small scale, Philippines. The conceptual framework of muḍāraba, mushāraka, and murābaha applied will create jurisprudence by itself (Sakili, 2000).

In an article, Datu Michael O. Mastura outlines the principles of Islamic financial institutions (banks) in the Philippines in the form of charity institutions, endowments, and the Islamic banking system. The agency manages a limited liability company, insurance, management agencies based on the principles of Islamic finance theory (Mastura, 1984). 
Islamic bank financial institutions in the Philippines are new phenomena within the Muslim minority. The economic system, which adopts the principles of the Islamic Bank, has already discussed and tested since 1974 as an aspiration. In the Philippines, the management of charity runs very well. The distribution is to the așnāf, for research at the university, as productive capital, and health funds.

\section{History of Islam Arrival in the Philippines}

History of Islam in the Philippines cannot be separated from the socio-cultural conditions of the region before the arrival of Islam. The Philippines is an archipelago country consisting of 7,107 islands. Its population is 47 million people using 87 different dialects that reflect the many tribes and ethnic communities. Before the arrival of Islam, the Philippines was a territory controlled by the kingdoms. Islam could enter and was well received by the locals because Islam could accommodate a variety of traditions they had so far (Esposito, 2002).

Historians find evidence of 16th century and 17th century from Spanish sources on religious beliefs of residents of Southeast Asia, including Luzon, which is part of the Philippines before the arrival of Islam. These sources provide an explanation that religious belief system that was dominant when Islam came in the 14th century with the requirements of various worship ceremony for the dead person. This is clearly not in line with Islamic teachings in terms of idolatry and polytheism. However, it seems that Islam could show them that this religion on its own way ensures the spirits of people who died in are in peace, which they could accept (www.lonelyplanet.com).

On the other hand, there is no doubt that the scale of Southeast Asian trade started to increase very rapidly at the end of the 14th century. The results of this trade, developing cities with astonishing speed, including along the coastal areas of the Philippine archipelago. The merchants of various countries met and gave rise to a good exchange in the field of science and religion.

Among all the major religions in the world, Islam is perhaps the most harmonious with the trading world. Al-Quran and al-Hadith as the highest source of Islam much praise to the merchant who could be trusted. This results in people who work in trading is definitely enamored with the teachings of Islam. From then on, Islam continues to expand its influence culturally, that are through inter-ethnic marriage and eventually through the political system. The last track (politics) occurs when the authorities, especially the king, have embraced Islam.

Arabic influence and the spread of Islam in the Philippines starts from Sulu brought by a sheikh who later married the daughter of the King of Sulu in the early 8th or 14th century. After that, it was also cited that a descendant of the Arab shaykh named Maldhum Karim or Tuan Sharif 'Awliya ' arrived in Sulu in the mid of 14th century. After that came an Arab preacher named Shaykh Abu Bakr or sharif al-Hashim from Makkah. Then, he was inducted as the Sulu sultanate and ruled for 30 years in 1450-1480. The Sultanate of Sulu then inherited by at least 32 sultans and the last was Sultan Jumal al-Karim II (1884-1936). 
From Sulu, Islam is then spread to Mindanao in the 10th century brought by 'Ali Zainal Abidin who was also known as "Kabungsuwan" which was a descendant of Syed' Awlawiyyah who have family ties with relative's king in Johor. The position and influence of "Kabungsuwan" was increasingly powerful that he succeeded to spread Islam to almost all residents of Mindanao and then initiated a sovereign Islamic kingdom there. The Islamic kingdom in Mindanao has been inherited by the family who then had expanded the Kabungsuwan Empire by conquering several other pieces of the Islamic empire, such as the Kingdom of Mindanao, Buayan kingdom, and the kingdom outside Butig (www.lonelyplanet.com).

\section{History of Islamic Civilization in Philippines}

Contribution from the Sayyed (ulamā') in the field of Islamic missionary endeavour was very large for the initial deployment of Islam in the Philippines. It was because they were already well-known as an expert in religion since they were in Hadramaut. The views and thoughts of people, especially Sayyed 'Alawiyyah on the religion were conservative patterned because they were not willing to accept any changes and updates. Such an attitude was a bit much influential to the Islamic community in this country in the following time (www.islamfilipina.com).

The next development of Muslims in the Philippines was that they called themselves as Moro. However, this name is actually more political, because in reality Moro consists of many ethno linguistic groups, for example the Maranao, Maguindanao, Tausug, Samal, Yakan, Ira Nun, Jamanapun, Badjao, Kalibugan, Kalagan, and Sangil. In social life, there was a fairly wide gap among Muslims Moro between the elites and the common traditional mass. Identification and ethnic consciousness occurred because of strong divisions of Muslims community geographically.

However, although there are variations and differences, there was a feeling of religious brotherhood especially when facing the same problems. It was not only the religion which united the Muslims in Philippines, but also economic difficulties and hardships experienced as a minority population made them feel the same fate. Policies to put Christians in Mindanao decades ago in the end of World War Il disturbed the traditional balance, and made detriment to the Muslim community. The influx of capital and large-scale technology to the Mindanao region in various economic sectors and industries in some cases resulted in the removal of the Muslim community as a traditional community. The Muslim community was very unfavourable. Those cases had led the spirit of the struggle in solidarity of missionary movement, and there therefore, it also emerged several Islamic organizations (www.islamfilipina.com).

There were Muslim Independence Movement (MIM in the '60s), the Moro National Liberation Front (MNLF) and the Moro Nation Army (BMA) which struggled for Muslims in the Philippines because they were exploited economically, political, and in social life. Most Moro people are fishermen and farmers. Moro people feel themselves to be different from the other Philippines. The real difference is not in the ethnic factor, due to the amount of nearly 100 ethnic groups in the Philippines, but rather on political history factors, region, religion, and socio-economic conditions (Majul, 1989). Considering their work activities, The Islamic Moro people also work in the government sectors as teachers, administrators, army, employees of the judicial office, and even elected as the governor. Muslims who received secular education tend to be able to blend with the other Philippines. 
On the other hand, those who do not want to receive the secular education and only get the traditional religious education, especially the local elite were educated in the Middle East, usually do not expect integration with the Philippines. There is a fairly wide gap among Muslim communities, especially between the traditional elites and the common masses. Identification and ethnic consciousness that occur due to the division of the Muslim communities geographically seems very strong. Although there are variations and differences, there is a feeling of religious brotherhood, especially when they are faced with the same problem.

As in other areas, Islam in the Philippines also experienced a significant revival. A Muslim scientist, Asiri Abu Bakr, outlines several factors that may contribute to the rise of Islam in the Philippines. They are: 1. Increasing relationship with the scholars and the educated Muslims of the Arab; 2 . The increasing number of Moro people who go on the hajj pilgrimage; 3 . the increasing opportunity to study in various Islamic centers throughout the world; 4 . the increasing active participation in various meetings in Islam world; 5 . The return of hundreds of Muslim students from abroad; 6 . The increasing number of established madāris (from madrasa; religious schools) in the regions; 7. The arrival of officials of the Islamic world to Moroland (Philippines); 8.the increasing of international press conference and ongoing coverage of the war in Mindanao and the violence committed by some military personnel in the region (Esposito, 2002).

\section{Spanish Colonial Period}

The Spain arrival to the Philippines in 1521 AD aims to spread Christianity, in addition to colonize. Spain could almost extend its sovereignty over the whole Philippine territory by force, persuasion, or subjecting subtly with gifts. The Spain conquered the northern region of the Philippines with ease and without any significant resistance, but not with the southern region. Spanish colonial soldiers had to fight against the Islamic empire in the southern Philippines, the Sulu, Manguindanau, and Buayan. The series of a long battle between Islam and Spain resulted nothing unless the increasing tension between Christians and Muslims in Philippines.

During the colonial period, Spain implemented the political of divide and rule and mission - sacre (the holy mission of Christianization) against the Muslims. Even the Muslims were stigmatized (nickname for the bad things) as "Moors" (Moro) meaning people who are illiterate, evil, godless, and huramentados (killers). Since then, the nickname attached to the Moro Islamic people who inhabited the southern Philippines. Year 1578 AD, there was a major war involving the Philippines. Spain also did bad inquisition against the Muslims in the Iberian Peninsula.

They attacked the Muslim in Sulu, Manguindanau and Manilad kingdoms with fanaticism and the same ferocity as they treated their own Muslim population in Spain. Even King Philip ordered the Chief of Navy as follows: "Conquer the islands and replace the religion of the inhabitants (to Catholicism)". Faced with this problem, the Muslims of the Philippines (Moro people) should fight for their survival until today, for more than four centuries. Spain was never able to conquer the Islamic sultanate of Sulu although they were in continuous wars, and finally they acknowledged the existence of Islamic sultanate of Sulu as an independent (www.islamfilipina.com). 


\section{Future US Imperialism}

In 1896, President Mc. Kinley from the US decided to occupy the Philippines to "Christianize and civilize" the people as he initiated. America came to Mindanao and presented themselves as a good and trustworthy friend. It was proved by the signing of the Treaty of Bates (August 20, 1898 AD) that promised freedom of religion, freedom of expression, and freedom of education for the Moro people. America managed to occupy the Spanish colony in 1899, but they met with resistance from Muslims in Sulu. The treaty was only a tactic to win hearts of the Muslims so that they would not rebel because at the same time America was preoccupied with the revolt of the North Philippine Revolutionary leader, Emilio Aguinaldo.

It was proven that after the revolutionaries were defeated in $1902 \mathrm{AD}$, the US policy in Mindanao and Sulu shifted into direct intervention and open occupation. A year later (1903 M) Mindanao and Sulu were incorporated into the province of Moro land to civilize the people of Mindanao and Sulu. The next period there was a record of the battle between the two sides. Sultanate of Sulu fell into American hands in 1914. In 1915, the King (Sultan; Sulțān) of Muslims was forced to abdicate, but was recognized as the head of the Muslim community. On April 1940, America abolished the Sultanate of Sulu and integrated the Moro people in the Philippines (Wilson, 2009)

It is noteworthy that during the period 1898-1902, the US appeared to have used the time to liberate the land and forests in the Moro region for expansion of the capitalist. Even period 1903-1913 the US spent to fight the Bangsamoro resistance groups. But Americans viewed the war is not enough to effectively the resistance of the Moro, America finally implement the strategy of colonization through education and persuasion policy.

This policy was later refined by the American people as a characteristic of their occupation. Education and persuasion policies applied America proved to be a very effective strategy in reducing the resistance of the Bangsamoro. As a result, political cohesion and unity among the Muslim community began to fall apart and cultural base began to be attacked by Western norms. Basically, this policy caused more Americans desire to enter the Muslims into mainstream society in the northern Philippines and Muslim assimilate people into the traditions and customs of Christians. Along with the reduction of the political power of the Sultan and the transfer of power gradually to Manila, this piecemeal approach threatens the long tradition of independence is maintained Muslim society (www.islamfilipina.com).

\section{The Transition Period}

The pre-independence period was marked by the transition of power from Americas colonial to the Philippines Christian government in the North. To integrate Moro land economy into the capitalist system, there were laws of the colonial legacy of US highly capitalistic such as the Land Registration Act No. 496 (November 1902) stating that land registration should be in writing, signed, and under oath. Then, there was also the Philippine Commission Act No. 718 (4 April 1903) stating that the granting of land from the Sultan, Datuk, or the head of the Non-Christian Tribes was considered as illegitimate if it was done without authority or permission from the government. 
The point was that the provisions of the law of this land were a legalization of the Muslims land confiscation (customary lands) by the US colonial government and the Philippine government in the North that benefited the capitalists. The easy land owning so easily and the legalization of the government encouraged massive migration and settlement of northern people to Mindanao (Esposito, 2002).

Many settlers in Kidapawan and Manguindanao admitted that the main motive of their arrival to Mindanao was to gain the land. To attract many settlers from the north to Mindanao, government built subsidized colonies completed with all the facilities needed. The Philippine government continued the concept of occupation through the colony after the US pulled out of the country. So, slowly but surely Moro people became minority in their own homeland.

\section{The Post-Independence Period / The Modern Period}

Philippines gained independence on July 4, 1946 from the US but it did not have a special meaning for the Moro people. The departure of the first colonizers (United States) from the Philippines created other invaders (the Philippine government). However, it should be noted that at the time, the Moro people efforts entered a new phase with the establishment of a more organized and advanced resistance fronts, such as MIM (Mindanao Independence Movement), MNLF, MILF, MNLFReformers, BMIF. At the same time, it was also splitting of Moro people forces into factions that weakened their struggle as a whole.

There were increasingly great pressure and weight on the Moro people when Ferdinand Marcos was in power (1965-1986). Compared to the reigns of Jose Rizal to the President Fidel Ramos, the reign of Ferdinand Marcos was the most repressive reign to the Moro. The formation of Muslim Independent Movement (MIM) in 1968 and the Moro Liberation Front (MLF) in 1971 could not be separated from Marcos' political stance. Next, the MLF as the leading organization of Moro's struggle eventually split into two. The first was the Moro National Liberation Front (MNLF) led by Nur Misuari with the ideology of nationalist-secular.

The second was Moro Islamic Liberation Front (MILF) led by Hashim Salamat, a scholar warrior, with the ideology of pure Islam and aimed at establishing an Islamic state in the southern Philippines.

But along the way, it turned out that MNLF led by Nur Misuari split into the MNLF-Reformist led by Pundato Dimas (1981) and the Abu Sayyaf led by Janjalani Abdurrazak (1993). Of course, this split weakened the overall Moro's struggle and strengthened the position of the Philippine government in facing of the Moro people. The signing of the peace treaty between Nur Misuari (MNLF chairman) with Fidel Ramos (President of the Philippines) on August 30, 1996 in the Merdeka palace indicated the disagreement of Moro people in resolving the conflict that entered the second decade (www.islamfilipina.com).

On the one hand, they wanted the completion of the conflict by diplomatic means (represented by MNLF), while others required armed struggle/jihād (represented by the MILF). All parties believed that their way was the most appropriate and effective. But apparently Ramos had to choose one of them although it was full of risks. "Everyone has to choose, it is impossible to satisfy all parties," he said. And there Moro people are, a minority in their own country. 
According to Majul, there are at least three reasons that cause difficulty of Moro people to fully integrate to the Philippines government:

a. Moro people are difficult to accept the National Law because obviously these laws come from the West and the Catholic, which are contrary to Islam.

b. The school system establishes the same curriculum regardless of differences in religion and culture that make the Moro people lazy to learn in schools established by the government.

c. The presence of trauma and deep hatred on the Moro people on the migration program conducted by the Philippine government to their regions in Mindanao because the program has changed them from the majority into a minority in all aspects of life.

An emergency condition in 1972 imposed by President Marcos led to further deterioration of law enforcement (Cf, Overholt, 1986, Rose-Ackerman, Desierto, and Volosin, 2010, Bankoff, 2007). The new society that Marcos wanted to build was an attempt to repair the evils that hit the Philippines as a country. Muslims of course were affected; but at the level of the government, they were given concessions. Muslims rebellion was seen as not worth and unnecessary. The Tripoli treaty, which attempted to stop the conflict between the MNLF and the government, was held. The government had taken the positive steps to show concern and good trust on this problem. One of them was the establishment of Philippine Pilgrimage Authority, an agency of development and well-being, and the implementation of family law for Muslims (www.islamfilipina.com).

From the above explanation, it is obvious that Islam entered the Philippines with no smooth road, winding, and full of the obstacles and barriers from inside and outside the country. Thus, in the early 1970s, Muslim people in the Philippines are the minority community and stay in some areas and special islands. The consequence of Muslim minorities who are not in line with the government's interest arises conflicts between the government and the Muslim community.

\section{Figures of Islamic Fighters in the Philippines}

\section{a. Prof. Dr. H. Nur Misuari}

Nur Misuari or Nurallaj Misuari is the founder of the Liberation Movement of Mindanao, which is an anti-royal community struggling using violence. Nur Misuari was imprisoned on charges of rebellion in 2006. Nur Misuari had been detained in Jampiras Island, Sabah 24 November 2001 because of entering Malaysia without valid travel documents.

The Kingdom of the Philippines urged Malaysia to hand Nur Misuari but Malaysia continued to protect Nur Misuari. Nur Misuari ever took refuge in Libya in early 1980s. Nur Misuari was a former governor of Muslim Autonomy Region of Mindanao (ARMM). He is 65 years old and be hunted by the government because of presiding the uprising on 19 November 2001 before fleeing. After the declaration of the law of the state of war, the MNLF (Moro National Liberation Front) became a prominent organization. And after the carnage of Jabidah, intellectuals including the students of Nur Misuari agreed that the Islamic community in the country would be well maintained at all if protected by strong armed forces. The central figure of the MNLF, Nur Misuari, was graduated from Philippines University majoring in Political Science and later served as rector, and then became a staff member at the Asia Centre of the University. He was from an ordinary Sulu family. 
The other leader is Hashim Salamat of Cotabato, Maguindanao. He is from an influential family, and studied in Arabic and Islam institutions in Cairo, Egypt. Another MNLF leader is Abdul Khair Alonto. $\mathrm{He}$ is a student and a descendant of the sultans in Lanao. Thus, MNLF represents all ethno linguistic groups and regions (Esposito, 2002).

\section{b. Abu Sayyaf}

The Abu Sayyaf, also known as Al Harakat Al Islamiyya (Al-Harākat Al-Islāmiyya), is a separatist group consisting of Muslim terrorists based around Jolo, Basilan, Mindanao, and the southern islands of the Philippines. Khadaffi Janjalani named as the leader of this group by the Armed Forces of the Philippines. It is reported that they are extending their networks in Malaysia and Indonesia. This group is responsible for the bombings, murder, kidnapping, and extortion as the effort to establish a Muslim state in the west of Mindanao and the Sulu islands and create a conducive atmosphere to the creation of a large state in the Pan-Islamic Malay Peninsula (Indonesia and Malaysia) in Southeast Asia. The group name is derived from Arabic for holder ( $A b u$ ) and sword (Șayyāf). Abu Sayyaf is one of the smallest and the most dangerous separatist group in Mindanao. Some members have studied or worked in Saudi Arabia and develop relationships with the mujāhidīn when fighting and training in Afghanistan and Pakistan (Esposito, 2002).

\section{Muslim Autonomy Region of Mindanao}

The Muslim capital city is Cotabato with Zaldy Ampatuan as governor. The total population is 2,803,805 people with the density level of $220.9 / \mathrm{km} 2$ in $12695.0 \mathrm{~km} 2 \mathrm{breadth}$. The languages are Maguindanao, Maranao, Tausug, Yakan, and Sama. Muslim Autonomy Region of Mindanao in the Philippines is a region consisting of the provinces of Islam in the country, namely: Basilan, Lanao del Sur, Maguindanao, Shariff Kabunsuan, Sulu, and Tawi-Tawi, and also a city inhabited by the Majority of Muslims, Marawi. This autonomic region is the only region in the Philippines, which has its own kingdom. The capital of this region is Cotabato. The region is devided into two geographic regions - the great land of Mindanao and the Sulu islands. Lanao del Sur, Maguindanao and Sharif Kabungsuwan are located in the large land of Mindanao, while Basilan, Sulu and Tawi-Tawi are in the Sulu islands (Wikipedia, Access on 5 March 2010).

\section{CONCLUSION}

When we do research and reviews on Islam in the Philippines, we should give priority to choose a study on the themes that have not been done by previous writers either in printed Encyclopaedias, and electronic Encyclopaedias (Google), Magazine, Journals, books, etc.

Themes such studies could be on issues related to religious texts circulating in the Philippines Muslim community in the early period of Islam (classical period), the colonization period (mid-term), and contemporary (modern times): The methodology used could be a comparison of the texts of works of scholars with the Worlds of Malay or Nusantara, or manuscript studies of the philology field of figh, Sufism or kalām. Considering the Islamic thought in the Malay Islamic tradition, the strength of scripts is the mainstream in the intellectual formation of social networks in the social history of Malay Islamic clumps. 
The problem is that whether or not Islamic manuscripts is still existing? Do Spanish and American colonization treats Muslim religious texts in Philippines the same?

Islamic educational institutions in the Philippines: the methodology could be the documents, oral history archives, a study of the existing Islamic educational institutions, religious curriculum, leaders of Islamic education, a model educational institution (are they the same as the Islamic boarding school, madrassa, dayeuh etc.). I believe that the study on Islamic education is still possible because the reality of Muslim students in Philippines still continues to develop, both within and to other Muslim countries.

Islamic tradition in Philippines. There is no complete research on the anthropological study on the pattern of family life, society, and the state. Economic relations, labour, philosophy of life, food and clothing, and family upbringing seem to leave and invite researchers to be creative in it. The methodology of social sciences, especially the "ethno-history" is clearly a tool to uncover the essence of Islam patterns in the Philippines more closely. Oral traditions, folklores, and forms of home buildings and families could be material to the search in a number of pockets of Muslims in Philippines.

Organizations of the Islamic movement. Although the study of Islamic movements has been widely conducted including the movement of Muslim leaders in Philippine themselves such as Cesar A. Majul, Nur Misuari, Nurallaj Misuari and many others, the researchers studying Islamic movement in Philippines are not able to connect to a network of Islamic movements in the Malay world, especially Indonesia. Studies of intelligence prove that the flow of struggles in Mindanao with the Moro is to the Islamic Aceh Movement (GAM).

The emergence of the terrorist leaders on behalf of the Jemaah Islamiyah (JI [Jamā'at Islāmiyya]) and its relationship with the Moro Islamic movement has not been fully studied in depth. Are there any similarities in the ideology and are the emergence of the roots of the radical Islamic movement with the national policies of their pro-Western governments related each other? There is possibility of Modern Islamic history to assess the contemporary Islamic movements. Sources could be from the manuscripts and oral diplomatic inter-state actors in the history of the movement.

Mental and social studies of the Philippines Muslim community and community clump countries. It is an interesting theme to uncover the social reality of modern Muslims in Philippines. Studies of social psychology could be conducted through seeing the Muslims labors from Philippines in performing their job responsibilities, their attitude towards the employer, their economic influence in social status and so on and it is an interesting theme to study. Social observation and in-depth interview on the Philippine Muslim workers are the entrance keys to obtain accurate information.

School of thought and Muslim pilgrimage traditions in Philippines from time to time. This field of study has not been disclosed in chronological order and in detail even though there are a lot of data and sources that explain the relation of Malay intellectuals and trading relations between them. Another similar study on the management of Hajj by Muslim autonomous government is still attractive for the development in the historiography of pilgrimage in Southeast Asia in general.

Those are some of the issues and ideas that are needed to develop in Islamic historiography development in Southeast Asia particularly in the Islamic region of the Philippines. My previous studies on "The Study on Malay Islamic Areas, from the Perspectives of ethno-linguistic and geopolitics" still leaves the materials that need to be developed. 
The point is that the historiography will continue to evolve in line with the interest of historians and their access to historical sources because historians rewrite history. Dialogue today represented by historians will continue be the object of studies until the end of time. Hopefully what we do is always beneficial. 


\section{References}

Adeoty, Ezekiel Oladele and adeyeri, James Olusegun. (2012). History, the Historian and His Work: Issues, Challenges and Prospect. International Journal of Educational Research and Technology 3 (4), pp. 36-41.

Ahmad, Kamaruzzaman Bustamam. (2007). The Application of Islamic Law in Indonesia: The Case Study Of Aceh. Journal of Indonesian Islam 1 (1), pp 135-180.

Aljunied, Syed Muhd Khairudin. (2004). Edward Said and Southeast Asian Islam: Western Representations of Meccan Pilgrims (Hajjis) in the Dutch East Indies, 1800-1900. Journal of Commonwealth and Postcolonial Studies 11 (1-2), pp. 159-175

Azra, Azyumardi, ed. 1989. Islam Di Asia Tenggara, Pengantar Pemikiran in, Perspektif Islam Di Asia Tenggara. Jakarta: Yayasan Obor.

Bankoff, Greg. (2007), Dangers to going it alone: social capital and the origins of community resilience in the Philippines", in Continuity and Change 22 (2), pp. 327-355. Cambridge University Press, https://dx.doi.org/:10.1017/S0268416007006315.

Benjamin, Jules R. (1982). A Student's Guide to History, Third Edition. New York: St. Martin's Press.

Bresnan, John. (1988). Krisis Filipina, Zaman Marcos Dan Keruntuhannya. Jakarta: Gramedia.

Cook, Terry. (2011). The Archive(s) Is a Foreign Country: Historians, Archivists, and the Changing Archival Landscape, in The American Archivist, Fall/Winter 74 (2), pp. 600-632.

Daneshgar, Majid. (2014). "The Study of Persian Shi'ism in the Malay- Indonesian World: A Review of Literature from the Nineteenth Century Onwards." Journal of Shi'a Islamic Studies, Spring VII (2), pp. 191-229. https://dx.doi.org/10.1353/isl.2014.0017.

Davary, Bahar. (2012). Islam and Ecology: Southeast Asia, Adat, and the Essence of Keramat. ASIA Network Exchange, fall. 20 (1), pp. 12-22.

Embong, Abdul Rahman. (2002). Malaysia as a Multicultural Society", in Macalester International, Fall. 12 (10), pp. 37-58.

Esposito, John L. (2002). Ensiklopedi Oxford Dunia Islam Modern 2, Indonesia Edition, Bandung: Mizan.

Hafid, Erwin. (2012). The Early of Islam in Indonesia. Journal of Islamic Civilization in Southeast Asia. 1 (2), pp. 1-11.

Hamid, Ahmad Fauzi Abdul. (2002). The Impact of Sufism on Muslims in Pre-colonial Malaysia: An Overview of Interpretations, Islamic Studies, 41 (3), pp. 467-493.

Hooker, M.B. (1983). Islam in Southeast Asia. Leiden: E. J. Brill.

Jalil, Mohd Noh Abdul. (2014). "The Roles of Malays in the Process of Islamization of the Malay World: A Preliminary Study." International Journal of Nusantara Islam. 02 (02), pp. 11-20. https://dx.doi.org/10.15575/ijni.v2i2.145. 
Jalil, Mohd. Noh Abdul. (2014). The Roles of Malays in the Process of Islamization of the Malay World: A Preliminary Study", in International Journal of Nusantara Islam, Vol. 2, No. 2, pp. 11-20, http://dx.doi.org/10.15575/ijni.v2i2.145.

Joseph Liow. (2015). The Arab Spring and Islamist activism in Southeast Asia: much ado about nothing? in Working Paper, Project on US Relations with the Islamic World at Brookings, Brookings Institute: Washington DC, August, pp. 12-3.

Kahin, George Mc. Turnan. (2003). South-East Asia: A Testament, Critical Asian Scholarship, edited by David Wurfel. London: Routledge.

Lombard, Denys. (1996). Nusa Jawa: Silang Budaya, Batas-Batas Pembaratan, Vol. I (Jakarta: Gramedia.

Majul, Cesar Adib. (1989). Suatu Analisa Terhadap Silisilah Sulu. In Islam di Asia Tenggara, edited by Ahmad Ibrahim and et al. Jakarta: LP3ES.

Mastura, Michael O. (1984). Muslim Filipino Experience: A Collection of Essays. Manila: Ministry of Muslim Affairs.

Meredith L. Weiss. (2010). Southeast Asia's Muslim Majority Democracies Elections and Islamism outside the MENA Region", Taiwan Journal of Democracy. 6 (1), pp. 81-106.

Negoita, Ana Maria. (2014). The Evolution of the Urbanistic Perspective in Islam - A Phenomenology of Urban Spaces and Urban Theory within a Historical Approach. Romanian Review of Political Sciences and International Relations. Tom. XI (1).

Overholt, William H. (1986). The Rise and Fall of Ferdinand Marcos. Asian Survey. 26, (11), pp. 1137-1163.

Rose-Ackerman, Susan; Desierto, Diane; and Volosin, Natalia. (2010). Leveraging Presidential Power: Separation of Powers without Checks and Balances in Argentina and the Philippines. Faculty Scholarship Series. Paper 31. http://digitalcommons.law.yale.edu/fss_papers/31.

Sakili, Abraham P. (2000). The Philipine Muslim: Our Link to Shouteast Asia. Kasarinlan 15 (1).

Shamsul A.B. (2005). Islam embedded: Religion and plurality in Southeast Asia as a mirror for Europe. Asia Europe Journal. pp. 159-178. https://dx.doi.org/10.1007/s10308-004-0114-8.

Shuhaimi, Mohd. Bin Haji Ishak. (2014). Nusantara and Islam: A Study of the History and Challenges in the Preservation of Faith and Identity. Australian Journal of Basic and Applied Sciences, 8 (9), pp. 351-359.

Thaib, Lukman and Pa, Bharuddin Che. (2013). Regional Cooperation: Malay World and the Formation of ASEAN Community, in Global Journal of HUMAN SOCIAL SCIENCE Political Science. 13 (2) Version 1.0, pp 8-16.

Thohir, Ajid. (2011). Studi Kawasan Dunia Islam Perspektif Etno-Linguistik Dan Geo-Politik. Jakarta: Rajagrafindo. 
Thomas, Nigel J.T. (2014). The Multidimensional Spectrum of Imagination: Images, Dreams, Hallucinations, and Active, Imaginative Perception. Humanities, 3 (2), pp. 132-184. https://dx.doi.org/10.3390/h3020132.

Wilson, MAJ. Thomas G. (2009). Extending the Autonomous Region in Muslim Mindanao to the More ILF a Catalyst for Peace, United Army. 
A Historical Overview and Initiating Historiography of Islam in the Philippines 